\title{
Do the ecological drivers of lake littoral communities match and lead to congruence between organism groups?
}

\author{
Kimmo T. Tolonen (1) J Juha Karjalainen • Heikki Hämäläinen • \\ Kristiina Nyholm • Minna Rahkola-Sorsa $\cdot$ Yongjiu Cai $\cdot$ Jani Heino
}

Received: 20 January 2020/ Accepted: 26 June 2020/Published online: 10 July 2020

(C) The Author(s) 2020

\begin{abstract}
Lake littoral environments are heterogeneous, and different organisms typically show specific responses to this environmental variation. We examined local environmental and spatial factors affecting lake littoral biodiversity and the structuring of assemblages of phytoplankton, zooplankton and macroinvertebrates within and among three basins of a large lake system. We explored congruence of species composition and species richness among the studied organism groups to evaluate their general indicator
\end{abstract}

Handling Editor: Télesphore Sime-Ngando.

Electronic supplementary material The online version of this article (https://doi.org/10.1007/s10452-020-09781-x) contains supplementary material, which is available to authorized users.

K. T. Tolonen $(\varangle) \cdot$ J. Karjalainen · H. Hämäläinen ·

K. Nyholm · M. Rahkola-Sorsa

Department of Biological and Environmental Sciences, University of Jyväskylä, P.O. Box 35, 40014 Jyväskylä, Finland

e-mail: kttolonen@gmail.com

K. T. Tolonen $\cdot$ J. Heino

Finnish Environment Institute, Freshwater Centre, Paavo Havaksen Tie 3, 90570 Oulu, Finland

Y. Cai

Key Laboratory of Watershed Geographic Sciences, Nanjing Institute of Geography and Limnology, Chinese Academy of Sciences, 73 East Beijing Road,

Nanjing 210008, China potential to represent spatial variation in other groups. We expected that effects of water chemistry on plankton assemblages were stronger than effects of habitat characteristics. In contrast, we anticipated stronger effects of habitat on macroinvertebrates due to their mainly benthic mode of life. We also expected that within-basin spatial effects would be strongest on macroinvertebrates and weakest on phytoplankton. We predicted weak congruence in assemblage composition and species richness among the organism groups. Phytoplankton assemblages were mainly structured by the shared effects of water chemistry and large-scale spatial factors. In contrast to our expectations, habitat effects were stronger than water chemistry effects on zooplankton assemblages. However, as expected, macroinvertebrate species composition and richness were mainly affected by habitat conditions. Among-group congruence was weak for assemblage composition and insignificant for richness. Albeit weak, congruence was strongest between phytoplankton and zooplankton assemblages, as we expected. In summary, our analyses do not support the idea of using a single organism group as a wholesale biodiversity indicator.

Keywords Lake littoral zone - Community structuring - Species richness - Environmental filtering $\cdot$ Spatial processes $\cdot$ Congruence 


\section{Introduction}

Freshwater biodiversity is currently jeopardized by various anthropogenic effects (Reid et al. 2019), which necessitates the use of robust and efficient biodiversity indicators (Heino 2015). The utility of different organism groups should, however, be reliably tested before they can be used in the assessments of lake ecosystems in practice. Biological communities of the lake littoral zone are studied less than, for example, pelagic planktonic and running-water communities. Previous studies have revealed that at larger among-lake spatial scale, water chemistry often primarily determines the composition and diversity of littoral communities provided that underlying environmental gradients are extensive enough (Jeppesen et al. 2000; McFarland et al. 2010; Alahuhta et al. 2013; Heino and Tolonen 2017). On the other hand, habitat characteristics including shoreline morphometry are the most important factors affecting biological communities in large lakes with extensive wind fetch but relatively limited water quality gradients (Tolonen et al. 2001, 2005; Tolonen and Hämäläinen 2010). In addition to local environmental conditions, spatial factors associated with organisms' dispersal rates or physical barriers (Mouquet and Loreau 2003; Heino et al. 2015) may be important in influencing littoral communities at both among-lake (Johnson and Goedkoop 2002; Heino and Tolonen 2017) and within-lake (Vilmi et al. 2016; Tolonen et al. 2017) spatial scales. At small scales, spatial structuring of biological communities may be related to mass effects, i.e. dispersal of abundant species from large source habitat patches to suboptimal conditions in smaller sink patches (Mouquet and Loreau 2003). On the other hand, dispersal limitation with low rates of dispersal and physical barriers to dispersal are more likely to create spatial community patterns at large spatial scales (Heino et al. 2015).

According to the metacommunity theory, local communities are structured by the interplay between local environmental conditions (environmental filtering), biotic interactions and regional dispersal-related processes (Leibold et al. 2004; Heino et al. 2015). The relative importance of environmental filtering and dispersal on the structuring of metacommunities is highly context specific and related to the spatial scales and environmental gradients covered (Heino et al. 2015), as well as organism groups, which differ in their species traits that mediate the effects of local environmental conditions and regional processes on local communities (De Bie et al. 2012; Heino 2013; Tolonen et al. 2018).

Currently, various international environmental legislations, commitments, agreements and platforms have been established to promote and aim towards the assessment and conservation of biodiversity (e.g. the European Biodiversity Strategy to 2020, EC 2011), ecosystem service supplies for human well-being (e.g. IPBES, www.ipbes.net) and ecological status of the environment (e.g. Water Framework Directive of the European Union, EC 2000). Effective assessment and management of freshwater ecological status and biodiversity require precise knowledge on the relationships of species and communities to their environment. In addition, information on biotic interactions and possible concordant responses of species assemblages to the environment are practical for biodiversity conservation and environmental assessment (Heino 2010). Possible cross-taxon congruence may result from the similar environmental responses among taxonomic groups (Allen et al. 1999a), biotic interactions (Gaston 2000), the concordant responses to regional processes (e.g. dispersal modes' similarities) (Allen et al. 1999b) and spatial scales examined (Westgate et al. 2014). Cross-taxon congruence would enable the use of surrogate taxa and save effort and money in the assessments of biodiversity and human impacts on the environment (Heino 2010,2015; Landeiro et al. 2012; Westgate et al. 2014). However, the congruence among taxa is typically weak and strongly context dependent (Heino 2010; de Morais et al. 2018).

In this study, we examined effects of local environmental conditions (water chemistry and habitat characteristics) and spatial location at two different spatial scales (within and among sub-basins) on the assemblage composition and species richness of three groups of organisms (i.e. phytoplankton, crustacean zooplankton and benthic macroinvertebrates) in the littoral zone across three basins of a large boreal lake system. We specifically aimed to identify differences in driving factors of assemblage composition and species richness among these organism groups. Due to their reliance primarily on planktonic mode of life, we expected that phytoplankton and zooplankton would be more strongly affected by water chemistry variables than by littoral habitat characteristics. On the 
other hand, a stronger association with habitat characteristics was expected for macroinvertebrates due to their predominantly benthic mode of life. We also expected a decreasing importance of local environmental conditions and an increasing importance of spatial factors (within and among basins) in structuring assemblages with increasing body size of organisms, from phytoplankton to zooplankton and finally to macroinvertebrates (see, e.g., De Bie et al. 2012). Further, we examined cross-taxon congruence in community composition and species richness among the three studied groups of organisms. We expected generally stronger congruence between the two plankton groups, whereas their associations with macroinvertebrates were expected to be weaker.

\section{Materials and methods}

\section{Study lake system}

Lake Saimaa located in Eastern Finland is the largest lake in Finland with a surface area of $4400 \mathrm{~km}^{2}$ and shoreline length of $14,850 \mathrm{~km}$. This lake system consists of several distinct, albeit connected, subbasins with divergent water chemistry depending on the catchment characteristics and intensity of human influence (Fig. 1). Lake Saimaa drains south into Lake Ladoga (Russia) and further into the Baltic Sea. We studied three sub-basins with differing water quality. Lake Puruvesi (surface area $407 \mathrm{~km}^{2}$, mean depth $11 \mathrm{~m}$ ) is an oligotrophic sub-basin with high water transparency and minor human impacts. Lake Pyhäselkä (surface area $229 \mathrm{~km}^{2}$, mean depth $10 \mathrm{~m}$ ), at the northernmost end of Saimaa system, is an oligomesotrophic sub-basin with water naturally moderately stained by humic substances. The lake receives efficiently treated pulp mill effluents and municipal sewage waters, creating a nutrient gradient subtly decreasing from north to south. The third sub-basin studied is situated in the northern part of Lake Haukivesi (surface area $514 \mathrm{~km}^{2}$, mean depth $9 \mathrm{~m}$ ). This mesotrophic sub-basin receives effluent and nutrient loading from wood-processing industry and municipal wastewaters.
Sampling and laboratory analyses of littoral organisms

In each of the three sub-basins studied, nine sampling sites representing three categorized habitat types (stony, sandy and vegetated/soft bottoms) were sampled from three depth zones: $0-0.5 \mathrm{~m}, 0.5-2 \mathrm{~m}$ and 2-3 m. Therefore, our sampling array of three habitat types $x$ three replicate sites of each habitat type $\times$ three depth zones at each sampling site resulted in a total of 81 samples of each organism group. Locations of sampling sites with species richness of the organism groups are shown in Figure S1. More detailed descriptions of sampling sites and methods used are given in Tolonen et al. $(2001,2005)$.

Phytoplankton samples were collected as a composite sample (total volume $20 \mathrm{~L}$ ) consisting of ten lifts of Ruttner-type tube sampler $(2 \mathrm{~L})$ in each of the three depth zones. Samples were mixed, sub-sampled with a glass bottle and fixed with acid Lugol's solution. Phytoplankton were mostly identified to species and when it rarely was not possible to genus level.

Crustacean zooplankton were sampled with a plankton pump or with a tube sampler as a pooled composite sample of each depth zone covering them vertically and horizontally. Total water volume sampled at each depth zone was $100 \mathrm{~L}$. The samples were preserved in $70 \%$ ethanol in the field and by adding $4 \%$ formaldehyde to the samples in the laboratory. Crustaceans were mostly identified to species level and counted using inverted microscope.

Littoral macroinvertebrates were sampled using a centrifugal pump (Robin PTG-201T) with a combustion engine as a power source (see Tolonen 2004, for details). On stony bottoms, the sample area was outlined by a circular steel frame with a surface area of $2827 \mathrm{~cm}^{2}$. The stones were brushed with a handbrush of a vacuum cleaner attached to the entrance hose of the pump. At each depth zone, three replicate samples covering a total surface area of $8481 \mathrm{~cm}^{2}$ were pooled. Sandy and vegetated muddy bottoms were sampled with a stiff fibreglass pipe with a $143 \mathrm{~cm}^{2}$ metal funnel attached to the end of the entrance hose. At sandy sites within each depth zone, the area of a pooled sample was $2577 \mathrm{~cm}^{2}$. At vegetated sites, the sample area was enclosed from sediment to water surface with a $1590 \mathrm{~cm}^{2}$ and $20 \mathrm{~cm}$ high round steel frame fixed to a $0.45 \mathrm{~mm}$ mesh net. The pooled samples at each 


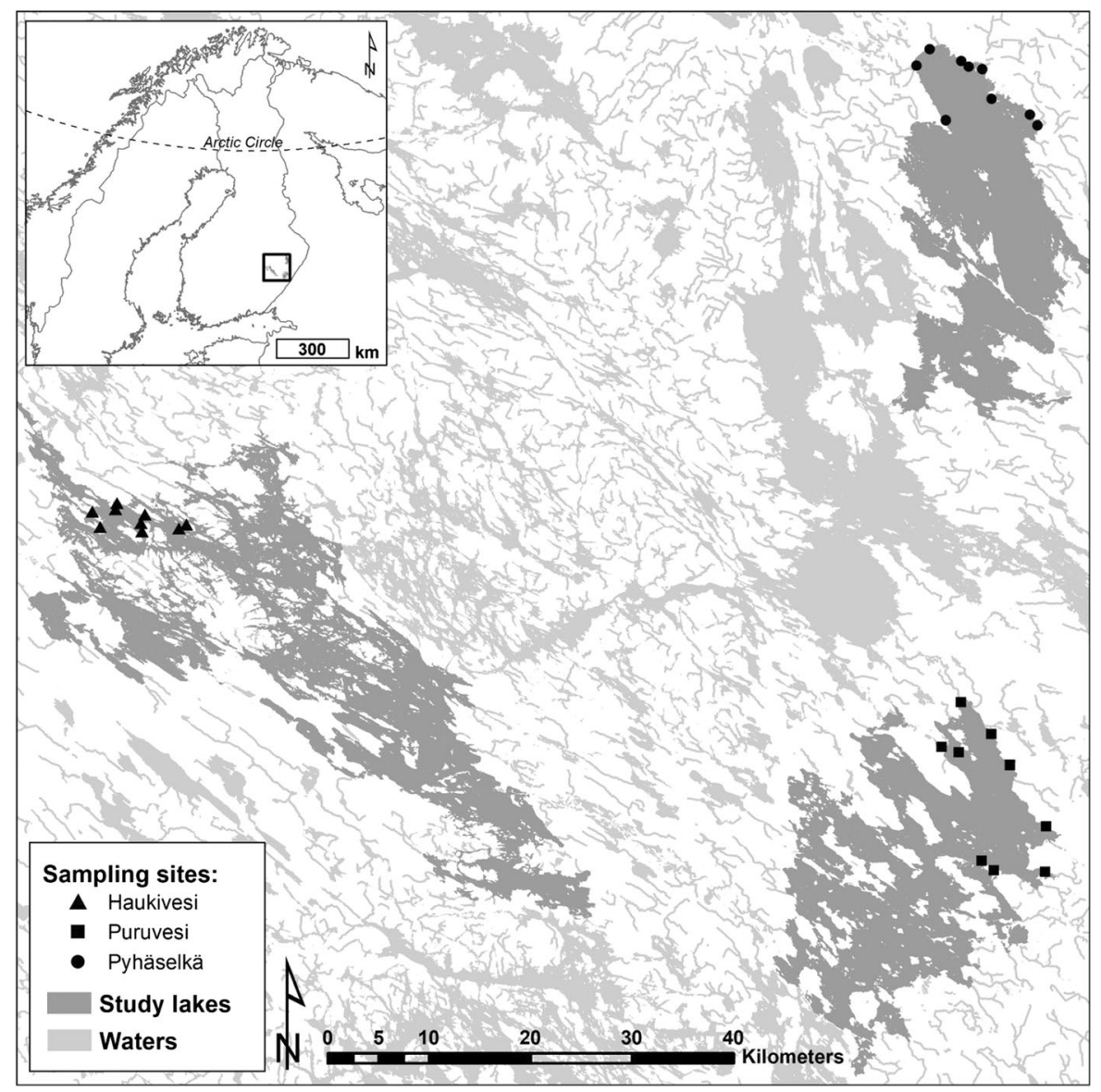

Fig. 1 A map showing the locations of the sampling sites in the three basins of the large Lake Saimaa system

depth zone comprised of three framed areas with a total surface area of $4770 \mathrm{~cm}^{2}$. The samples were preserved in $70 \%$ ethanol in the field. Macroinvertebrates were counted and identified to species, species group or genus level in the laboratory.

\section{Environmental variables}

Water samples were taken with a Ruttner-type sampler as composite samples from each of the three depth zones. Water quality parameters, including total phosphorus (TP), total nitrogen (TN), chlorophyll-a, water colour, conductivity, $\mathrm{pH}$ and turbidity, were analysed from these samples using Finnish standard methods (National Board of Waters and the Environment 1981). Secchi depth for water transparency was measured for each site at the 2-3 m depth zone, and when Secchi depth was over $3 \mathrm{~m}$, in deeper water in front of the littoral site. All these variables (Table 1) were included in the explanatory environmental variable group of 'water chemistry', for further analyses.

At each site, the distance from shoreline to depth of $2 \mathrm{~m}$ was measured along the water surface to obtain bottom slope, which was expressed as an angle $\left(^{\circ}\right)$ between water and bottom surfaces. Wind fetch $(\mathrm{km})$ describing wind exposure and wave disturbance at each site was measured according to Duarte and Kalff (1986). All aquatic macrophyte stems were collected from three square plots of $1 \mathrm{~m}^{2}$ in each depth zone. All plants were identified to species, counted, dried and weighted in the laboratory. The macrophyte biomasses (DW $\mathrm{g} \mathrm{m}^{-2}$ ) were pooled among four life forms: emergents, floating-leaved, elodeids and isoetids. Biomasses of macrophyte life forms together with bottom slope and wind fetch comprised the explanatory variable group of 'habitat characteristics', for further analyses. 
Table 1 Means and ranges (in brackets) of environmental variables in the three studied lake basins

\begin{tabular}{|c|c|c|c|}
\hline & L. Puruvesi & L. Pyhäselkä & L. Haukivesi \\
\hline \multicolumn{4}{|l|}{ Water chemistry } \\
\hline Total phosphorus $\left(\mu \mathrm{g} \mathrm{L}^{-1}\right)$ & $5(3-7)$ & $13(8-19)$ & $19(13-26)$ \\
\hline Total nitrogen $\left(\mu \mathrm{g} \mathrm{L}^{-1}\right)$ & $281(222-321)$ & $408(371-482)$ & $476(381-570)$ \\
\hline Conductivity $\left(\mu \mathrm{S} \mathrm{cm}^{-1}\right)$ & $49(48-50)$ & $36(34-41)$ & $66(57-70)$ \\
\hline Water colour $\left(\mathrm{mg} \mathrm{Pt} \mathrm{L}^{-1}\right)$ & $8(5-15)$ & $60(40-80)$ & $39(35-40)$ \\
\hline $\mathrm{pH}$ & $7.5(7.1-7.8)$ & $7.1(6.5-7.3)$ & $7.3(7.2-7.4)$ \\
\hline Turbidity, FTU & $0.8(0.6-1.2)$ & $1.6(0.7-2.6)$ & $2.6(1.4-3.4)$ \\
\hline Secchi depth (m) & $7.5(5.0-9.0)$ & $2.2(2.0-2.5)$ & $2.3(2.0-3.1)$ \\
\hline \multicolumn{4}{|l|}{ Habitat characteristics } \\
\hline Wind fetch $(\mathrm{km})$ & $1.5(0.6-2.7)$ & $3.0(0.8-5.9)$ & $0.5(0.2-1.0)$ \\
\hline Slope $\left(^{\circ}\right)$ & $3.1(0.2-9.9)$ & $1.7(0.4 .6 .1)$ & $3.2(1.1-6.3)$ \\
\hline Biomass of emergents (DW $\mathrm{g} \mathrm{m}^{-2}$ ) & $25.1(0.0-457.1)$ & $84.8(0.0-869.3)$ & $17.0(0.0-187.6)$ \\
\hline $\begin{array}{l}\text { Biomass of floating-leaved (DW } \mathrm{g} \mathrm{m}^{-2} \text { ) Biomass of emergent (DW } \\
\mathrm{g} \mathrm{m}^{-2} \text { ) }\end{array}$ & $0.1(0.0-3.0)$ & $2.4(0.0-31.7)$ & $3.7(0.0-37.5)$ \\
\hline Biomass of elodeids (DW $\mathrm{g} \mathrm{m}^{-2}$ ) & $0.6(0.0-3.8)$ & $0.4(0.0-6.8)$ & $0.9(0.0-9.6)$ \\
\hline Biomass of isoetids (DW $\mathrm{g} \mathrm{m}^{-2}$ ) & $3.3(0.0-20.5)$ & $0.0(0.0-0.2)$ & $0.0(0.0-0.4)$ \\
\hline
\end{tabular}

Statistical analyses

We used a similar statistical treatment for our aquatic community data as Declerck et al. (2011) in their study of metacommunities across a set of ponds. We conducted redundancy analyses (RDA) for the species composition of phytoplankton, zooplankton and benthic macroinvertebrate communities. In the RDA, we divided explanatory variables into four groups of candidate predictors. First, (A) water chemistry and (B) habitat variables represented local environmental conditions. Second, we used spatial predictors at two different spatial scales: (C) distance-based Moran's eigenvector maps (dbMEMs, Dray et al. 2012) were used to measure within-basin spatial variation, whereas (D) lake basins as dummy predictors represented larger-scale spatial variation.

We conducted principal coordinates of neighbour matrix analysis (PCNM) using R package PCNM (Declerck et al. 2011) to obtain smaller within-basin scale spatial variables. Eigenvectors produced by the PCNM analysis are equivalent to distance-based Moran's eigenvector maps (dbMEMs) (Dray et al. 2013), and we refer them hereafter to dbMEMs. These eigenvectors take into account complex spatial interactions among sites, including nonlinear patterns and those occurring at multiple spatial scales. We generated dbMEMs individually for each of the three studied sub-basins. The analysis resulted in three dbMEMs for Puruvesi (MEM1-MEM3) and Haukivesi (MEM9-MEM11) sub-basins and five eigenvectors (MEM4-MEM8) for Pyhäselkä.

We conducted a preselection of environmental and spatial predictors to avoid problems of multicollinearity and to facilitate interpretations of the RDA results. We selected only one variable considered to be the most influential one among the strongly correlated $(r>0.6)$ candidate predictors within each group of predictors. In the first phase of RDA, we used each group of candidate predictors separately and selected statistically significant predictors using a conservative forward selection method with 1000 permutations (Blanchet et al. 2008) and the ordiR2step function in the $\mathrm{R}$ package vegan (Oksanen et al. 2013). Second, we conducted variation partitioning in RDA among four groups of predictor variables (i.e. two groups of environmental and two groups of spatial predictors) using the varpart function in the vegan $\mathrm{R}$ package. In addition, we examined congruencies in species composition among organism groups using Hellinger distance-based Mantel tests using the function mantel in vegan (Oksanen et al. 2013).

We also explored which environmental variables were associated with species richness variation in the 
studied three organism groups. The surface area of macroinvertebrate samples varied among habitat types, and varying sub-sample sizes were used in zooplankton counting and identification. Therefore, we standardized species richness of zooplankton and macroinvertebrates for the same numbers of individuals (141 and 41, respectively) using the function rarefy in vegan. For explaining variation in species richness, we used multiple regression analyses with a conservative forward selection (Blanchet et al. 2008) using the same principles as explained above for RDA-based analyses. As for RDA-based analyses, we also conducted variation partitioning among the four groups of explanatory variables. We also tested for congruence in species richness between organism groups using Pearson's correlation analysis $(\alpha=0.05)$.

\section{Results}

Variation in local community structure

The RDA model accounted for $49 \%$ of the variation in assemblage composition of littoral phytoplankton (Fig. 2). Phytoplankton community composition was characteristic to the basins of the lake system, as $40 \%$ of the total variation was related to basin and unique proportion explained by the basin alone was $10 \%$. This lake basin effect was clearly illustrated by the nonoverlapping arrangement of sites of different study basins in the ordination space. Within-basin spatial variables (MEMs) were not significantly related to phytoplankton composition (Blanchet selection, $P>0.05)$. Total phosphorus, conductivity and $\mathrm{pH}$ were the water chemistry variables significantly associated with phytoplankton composition (forward selection, $P<0.01)$. These variables accounted for $34 \%$ of the total variation in phytoplankton community composition. However, unique proportion of variance explained by water chemistry variables alone was only $4 \%$. Environmental variables associated with habitat characteristics explained $15 \%$ of the total variance in phytoplankton composition, of which only $3 \%$ was explained uniquely by these variables, namely wind fetch, depth and biomass of isoetid macrophytes.

The RDA model for the species composition of zooplankton explained 34\% of the variance (Fig. 3). Zooplankton species composition was most strongly associated with habitat variables, i.e. depth, wind fetch and biomass of isoetid macrophytes (Blanchet selection, $P<0.01$ ). These variables explained $17 \%$ of the total variation in zooplankton composition, with $7 \%$ unique proportion explained. Water chemistry variables, including total phosphorus, conductivity and Secchi depth, accounted for $18 \%$ and $3 \%$ of variation

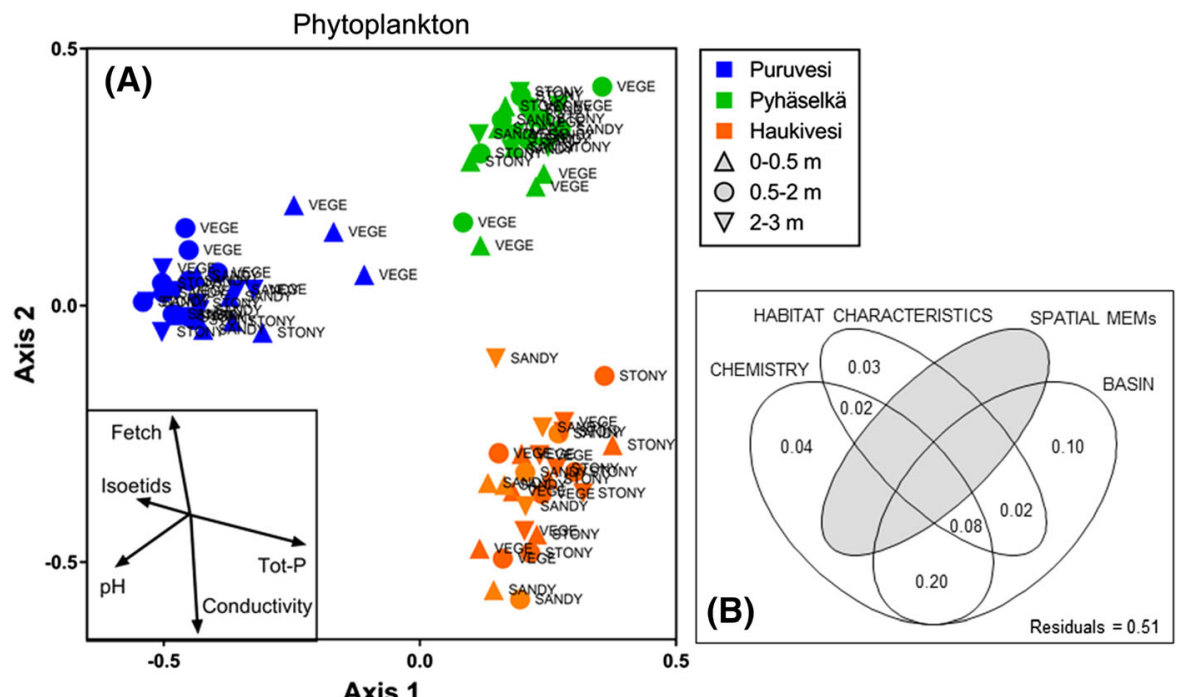

Fig. 2 a RDA-based ordination of phytoplankton. b Variation partitioning among the effects of water chemistry, habitat characteristics, within-basin spatial variables (spatial MEMs) and lake basin on the community composition of phytoplankton. Spatial MEMs explained zero variation in the model, which is indicated by the grey ellipse in the Venn diagram 
Fig. 3 a RDA-based ordination of zooplankton. b Variation partitioning among the effects of water chemistry, habitat characteristics, within-basin spatial variables (spatial MEMs) and lake basin on the community composition of zooplankton

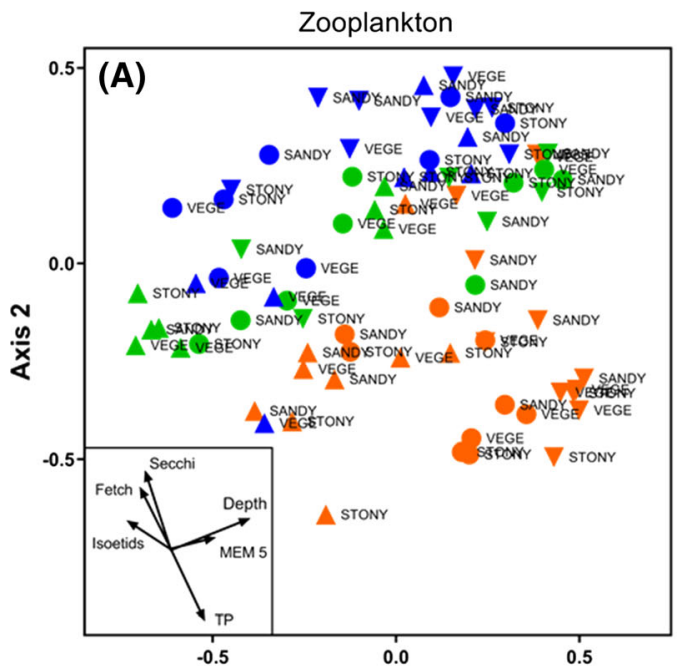

Axis 1
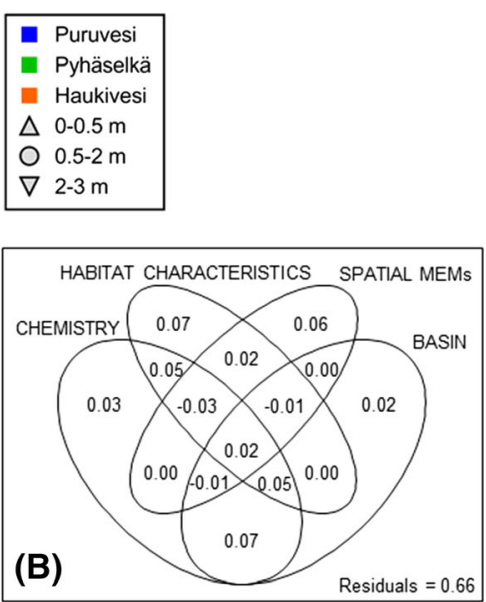

in total and uniquely, respectively. The unique share of explained variation was $6 \%$ for within-basin spatial variables (MEMs). Lake basin accounted for $14 \%$ of variance in zooplankton composition, when the unique share explained was only $2 \%$.

The RDA model accounted for $35 \%$ of the variance in littoral macroinvertebrate species composition. Depth, wind fetch, bottom slope, biomass of isoetid and elodeid macrophytes related to habitat characteristics were the most influential variables. These variables accounted for $15 \%$ unique and $23 \%$ total proportion of variance in species composition (Fig. 4). The unique proportion of variance explained by water chemistry variables (TP, conductivity and $\mathrm{pH}$ ) was only $2 \%$. In addition, water chemistry shared $6 \%$ of the explained variation with other explanatory variables. The unique shares of explained variation for withinand among-basin spatial effects were $5 \%$ and $3 \%$, respectively.

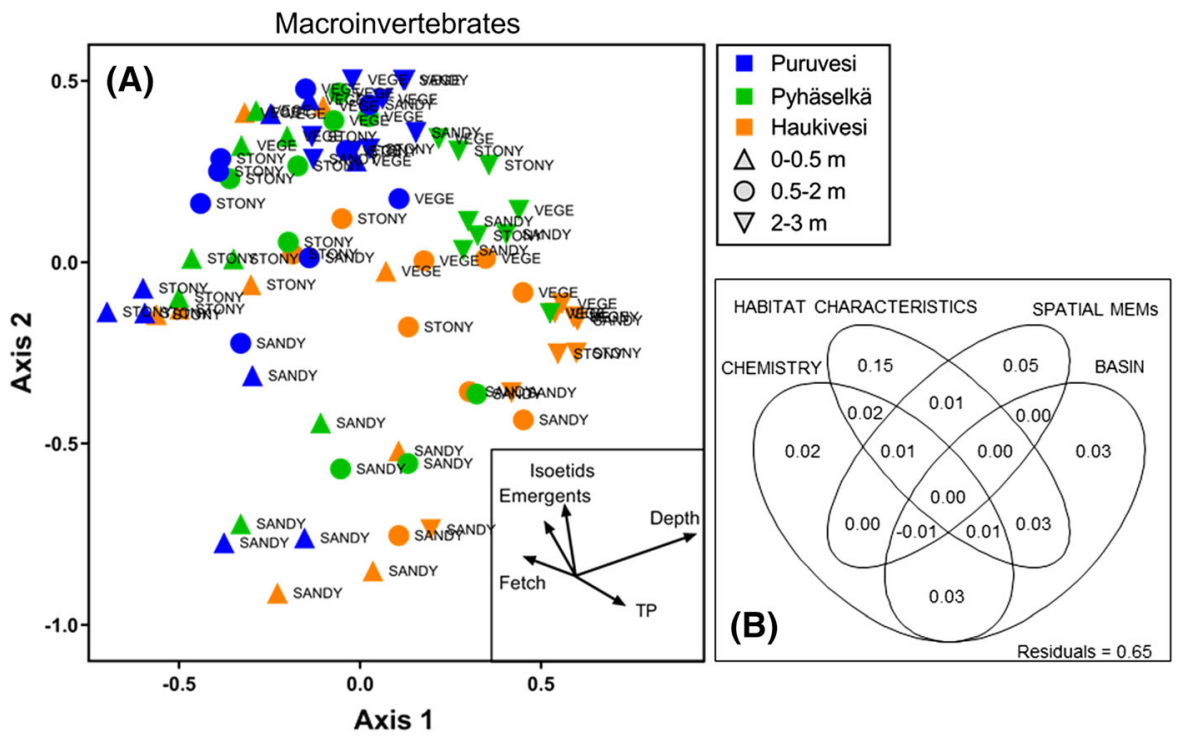

Fig. 4 a RDA-based ordination of macroinvertebrates. b Variation partitioning among the effects of water chemistry, habitat characteristics, within-basin spatial variables (spatial MEMs) and lake basin on the community composition of macroinvertebrates 
Congruence in community composition between the organism groups

Mantel tests indicated weak, yet significant $(P<0.001)$, congruence between all the pairs of the three studied organism groups (Fig. 5). The strongest congruence was observed between phytoplankton and zooplankton assemblages $(r=0.34)$, and the weakest between phytoplankton and macroinvertebrates $(r=0.20)$.

\section{Variation in species richness}

Of the candidate local environmental predictors, only total phosphorus concentration (with a positive relationship) explained a significant amount of variation (40\%) in species richness of phytoplankton (Table 2). However, the proportion of variation attributed to total phosphorus was almost completely shared with subbasin (39\%), which had an additional 4\% unique contribution to the total variation explained (44\%). Neither within-basin spatial MEMs predictors nor the habitat characteristics were significantly related with the variation of phytoplankton species richness $(P>0.05)$.

The species richness of zooplankton was significantly associated with water depth, wind fetch and total phosphorus, which together explained $23 \%$ of variation (Table 2). Zooplankton richness was most strongly related to habitat variables (water depth and wind fetch), which uniquely explained $16 \%$ of variation (Fig. 6), whereas the remaining fractions associated with unique total phosphorus effects (4\%) or were shared effects of sub-basin and environmental predictors.

The species richness of littoral macroinvertebrates was significantly associated only with water depth, bottom slope and the biomass of emergent macrophytes (Table 2, Fig. 6). These variables related to habitat characteristics together explained $25 \%$ of the variation. The association with water depth tended to be humped, species richness most often peaking at intermediate depths (see map showing species richness in each depth zone and at each of the sampling sites, Fig. S1-3). Macroinvertebrate richness increased with increasing biomass of emergent macrophytes. After accounting for other significant variables, the bottom slope with positive relationship was also selected to the model explaining variation in species richness. However, when the macroinvertebrate richness-bottom slope relationship was examined alone, this relationship was concave upward with the lowest richness at the intermediate bottom slopes.

\section{Congruence in species richness}

Congruence of species richness between the pairs of organism groups was weak or negligible (Fig. 7). The species richness of phytoplankton and zooplankton was weakly positively $(r=0.20)$, but not significantly correlated $(P=0.083)$. Macroinvertebrate richness did not correlate significantly neither with the richness of phytoplankton nor with the richness of zooplankton.

\section{(A)}

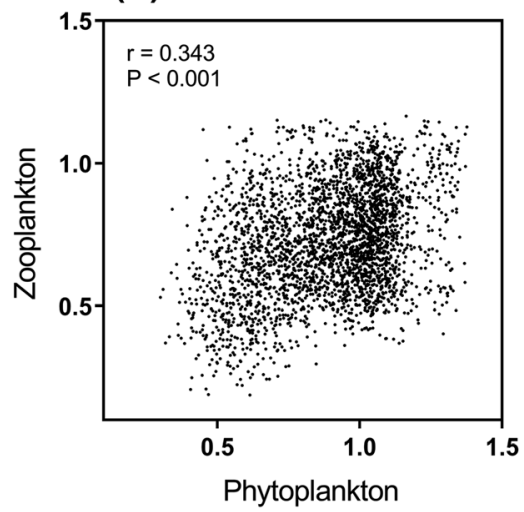

(B)

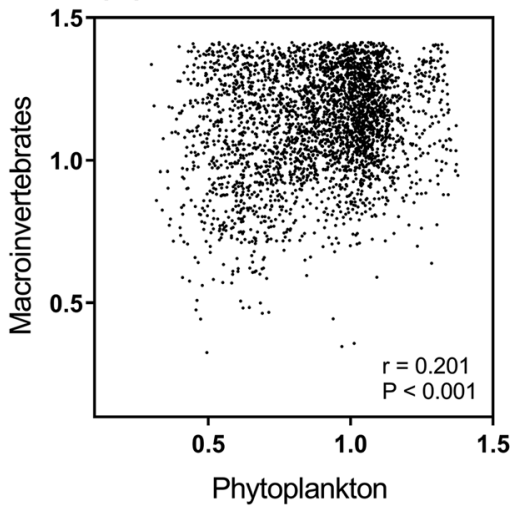

(C)

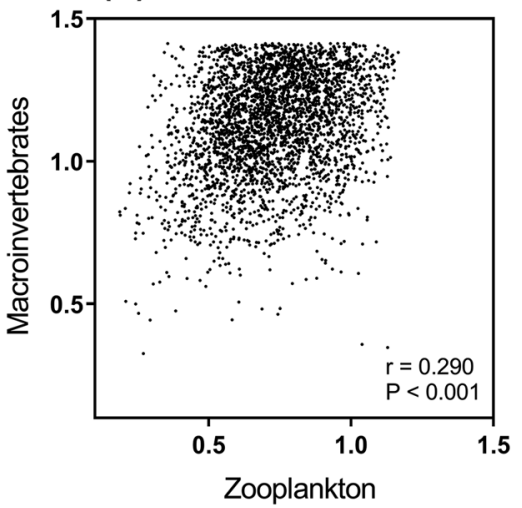

Fig. 5 Congruencies in community composition between a phytoplankton and zooplankton, b phytoplankton and benthic macroinvertebrates and $\mathbf{c}$ between zooplankton and benthic macroinvertebrates. Units of the axes are Hellinger distances. Mantel test statistics are shown in the scatterplots 
Table 2 The results of multiple regression analyses for the effects of local environmental variables and spatial variables on the species richness of phytoplankton, zooplankton and benthic macroinvertebrates

\begin{tabular}{|c|c|c|c|c|c|}
\hline & Estimate & SE & $t$ & $P$ & $\operatorname{Adj.} R^{2}$ \\
\hline \multicolumn{6}{|l|}{ Phytoplankton } \\
\hline Intercept & 24.23 & 5.54 & 4.38 & $<0.001$ & \\
\hline Log tot-P & 37.32 & 5.12 & 7.28 & $<0.001$ & 0.40 \\
\hline \multicolumn{6}{|l|}{ Zooplankton } \\
\hline Intercept & 8.52 & 1.70 & 5.01 & $<0.001$ & \\
\hline Log tot-P & 3.65 & 1.21 & 3.03 & 0.003 & \\
\hline Depth & -1.09 & 0.31 & -3.54 & 0.001 & \\
\hline Log fetch & 3.35 & 1.45 & 2.31 & 0.024 & 0.23 \\
\hline \multicolumn{6}{|c|}{ Macroinvertebrates } \\
\hline Intercept & 5.08 & 1.80 & 2.82 & 0.006 & \\
\hline Depth & 9.28 & 2.17 & 4.29 & $<0.001$ & \\
\hline Depth $^{2}$ & -2.61 & 0.73 & -3.58 & $<0.001$ & \\
\hline Log slope & 5.96 & 1.74 & 3.43 & $<0.001$ & \\
\hline Log emergents & 1.80 & 0.64 & 2.83 & 0.006 & 0.25 \\
\hline
\end{tabular}

(A)

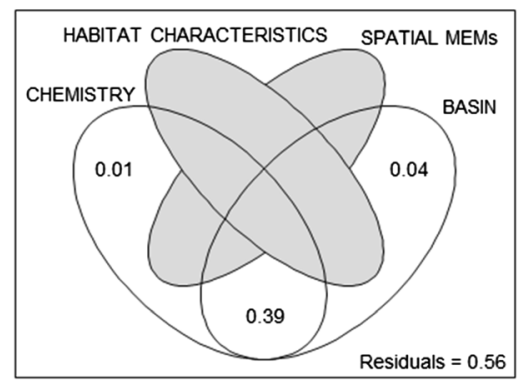

Fig. 6 Variation partitioning among the effects of water chemistry, habitat and littoral morphometry variables, withinbasin spatial variables (spatial MEMs) and lake basin on the species richness of a phytoplankton, b zooplankton and
(B)

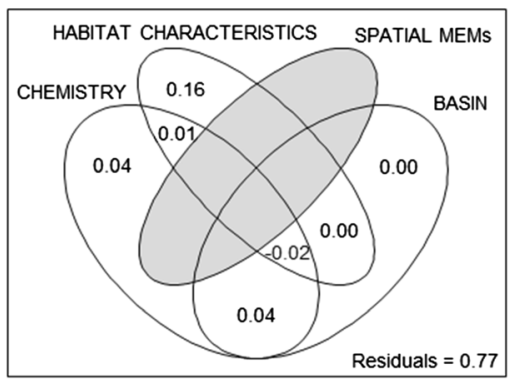

(C) Macroinvertebrates

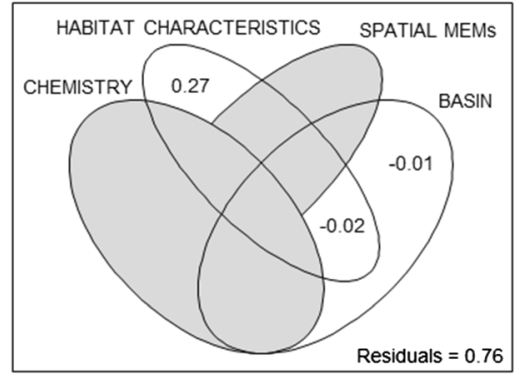

c macroinvertebrates. Zero explained variations in the models by variable groups are indicated by the grey ellipses in the Venn diagrams
(A)

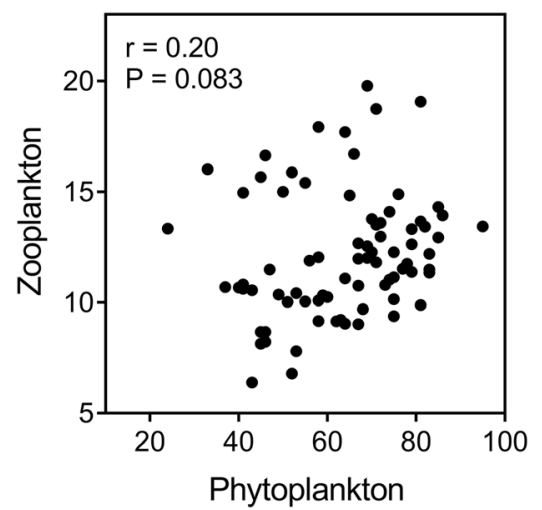

(B)

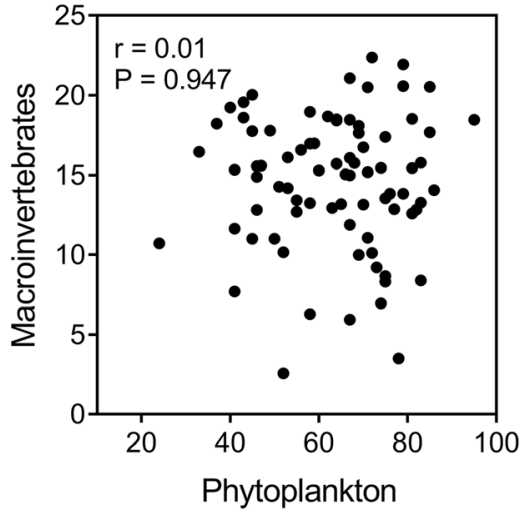

(C)

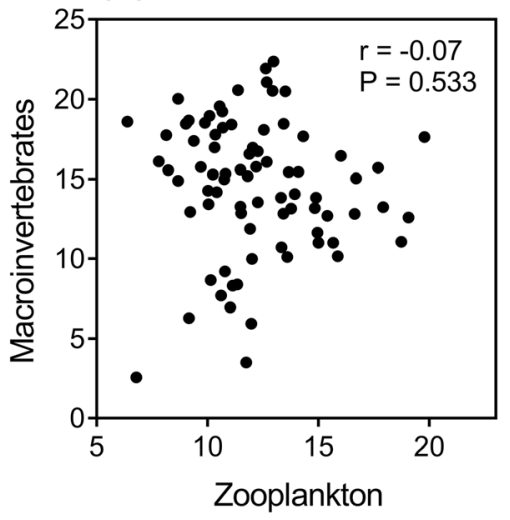

Fig. 7 Pairwise congruencies in species richness between a phytoplankton and zooplankton, b phytoplankton and benthic macroinvertebrates and $\mathbf{c}$ between zooplankton and benthic macroinvertebrates. Pearson correlation coefficients $(r)$ and significance values $(P)$ are shown in the scatterplots 


\section{Discussion}

As expected, we observed that the local community structure of phytoplankton and zooplankton was more strongly associated with water chemistry compared with the community structure of littoral macroinvertebrates, which was more strongly affected by habitat variables (Fig. S4, see also Tolonen et al. 2001; Tolonen and Hämäläinen 2010). However, in contrast to our expectations, zooplankton assemblages were also apparently more strongly structured by habitat variables than by water chemistry. The observed positive association with total phosphorus differing at the among-basin level suggests that environmental effects on species richness of phytoplankton are mainly related to water chemistry. Also, in agreement with our predictions, the species richness of macroinvertebrates was related to habitat characteristics. In contrast to our a priori expectations, spatial effects on phytoplankton assemblages were slightly stronger than those on the other assemblages, whereas unique effects of local environmental conditions increased from phytoplankton to macroinvertebrates. On the other hand, total variation explained by local environmental conditions in phytoplankton community composition was higher than that in zooplankton and macroinvertebrate communities (Fig. S5). All between-organism group congruencies in assemblage composition were weak, but stronger between phytoplankton and zooplankton than between macroinvertebrates and the planktonic groups. On the other hand, there were no significant correlations in species richness among the three organism groups.

Patterns in local community structure

We observed strong water chemistry and lake basinlevel spatial effects on phytoplankton community composition. Water chemistry effects on phytoplankton were mainly related to nutrient concentrations and conductivity. The controlling effect of nutrients on phytoplankton community composition and productivity is a well-established phenomenon, and this effect is relatively much stronger along more extensive nutrient gradients (Duarte et al. 1992; Watson et al. 1997) than the effect observed along a relatively short nutrient gradient of this study. Assemblage composition was also attributed to wind fetch in our study lakes. Wind conditions can directly affect the distributions and patchiness of planktic communities and indirectly via water quality changes, for example, by sediment resuspension (Blukacz et al. 2009; Cardoso and Motta Marques 2009). We also found a significant relationship between isoetid macrophyte abundance and phytoplankton assemblage composition. Earlier studies have highlighted the effects of macrophytes on phytoplankton communities pointing out the alternative macrophyte-dominated clear-water states and phytoplankton-dominated turbid states (Scheffer et al. 1993; Nõges et al. 2003). Negative effects of macrophytes on phytoplankton may be related to several factors that include increased zooplankton grazing (Jeppesen et al. 1999) and sinking loss of phytoplankton (Pluntke and Kozerski 2003) among macrophyte beds and influences of allelochemicals released by macrophytes on phytoplankton (Hilt and Gross 2008). We observed spatial effects on the phytoplankton assemblage structuring at the larger among-basin scale, whereas no spatial effects were detected at within-basin scale. The unique effects of among-basin scale on phytoplankton assemblage structuring were, in fact, larger than unique effects of all environmental variables analysed in this study. However, water chemistry was strongly spatially structured across our study sites, as the levels of nutrient concentrations were distinct among lake basins. Therefore, and because environmental filtering generally prevails in structuring phytoplankton communities at spatial scales comparable to our study (Soininen and Luoto 2012; Maloufi et al. 2016), we suppose that a large shared fraction explained together by water chemistry and lake basin may probably be related to differences in nutrient concentrations between lake basins rather than to spatial effects. Generally, small-sized passive dispersers, such as phytoplankton, are considered effective dispersers and, therefore, phytoplankton communities are often structured mainly by environmental filtering at small to medium spatial scales (e.g. De Bie et al. 2012). Similar to the results observed here, Soininen et al. (2011) found significant spatial effects on the phytoplankton only at the larger among drainage basin scale and no spatial structuring at smaller within drainage basin scale.

Zooplankton assemblage structuring was most strongly associated with habitat characteristics in our study lakes. These variables included water depth, wind fetch and isoetid macrophyte abundance. The 
effects of water depth and macrophyte abundance may relate to the diel horizontal migrations of zooplankton between open water and macrophyte beds, which are induced to avoid fish predators (Lauridsen et al. 1996; van Donk and van de Bund 2002). In addition, some specialist zooplankton species are typically associated with macrophytes (Lauridsen et al. 1996). Zooplankton assemblage structure was also significantly related to water transparency and nutrient concentration in our study lakes. Lake trophic status effects on zooplankton community composition and size structure are well known (e.g. Jeppesen et al. 2011). These changes usually occur in tandem with the changes in phytoplankton and fish communities along a trophic gradient, where top-down effects in planktonic food webs are applied to lake management by biomanipulation (Gulati and van Donk 2002; Jeppesen et al. 2003). In addition to the effects of local environmental conditions, we also identified apparently unique spatial influences on the structuring of zooplankton assemblages. These effects were stronger at smaller withinbasin scale than among lake basins. The crustacean zooplankton species studied here are generally considered effective passive dispersers using multiple dispersal vectors including wind and waterfowl for overland dispersal, and water currents and fish for dispersal within waterbodies (Jarnagin et al. 2000; Havel and Shurin 2004; De Bie et al. 2012). Moreover, temporal dispersal capacity of crustacean zooplankton by the diapausing eggs in the lake sediments (up to hundreds of years) (Hairston et al. 1995; Havel and Shurin 2004) increases their overall dispersal ability. The possible existence of within-lake spatial patterns observed in our study systems may be related to active horizontal movements and within-lake habitat selection of zooplankton (e.g. Lauridsen et al. 1996) and biologically driven patchiness (e.g. Folt and Burns 1999).

We observed that the community structuring of macroinvertebrates was most strongly influenced by habitat characteristics in our study lake basins. Similarly, earlier studies at within-lake among-habitat (Tolonen and Hämäläinen 2010) and within-lake within-habitat (Vilmi et al. 2016) scales in large lakes systems have indicated the importance of habitat characteristics and shore morphometry over other variables. However, among-lake among-habitat-type studies in smaller lakes have indicated that along wider water chemistry gradients or with less habitat variability, water chemistry is equally or more important than habitat characteristics in structuring littoral macroinvertebrate metacommunities (White and Irvine 2003; Brauns et al. 2007; Heino and Tolonen 2017). As shown by earlier studies (Tolonen et al. 2001; Tolonen and Hämäläinen 2010), controlling for natural habitat variability may be useful for environmental assessment purposes to better detect water chemistry effects. In addition to the influences of local environmental conditions, our analyses suggested unique effects of spatial factors on macroinvertebrate assemblages. These effects were stronger at the within-lake than at the among-lake scale. Similarly, earlier studies on littoral macroinvertebrate communities of large lakes have detected significant spatial effects on species composition at the within-lake scale (Vilmi et al. 2016; Tolonen et al. 2018). Tolonen et al. (2018) observed that the magnitude of spatial withinlake effects was greater for small-sized species than for larger species. This may be due to increasing active dispersal and habitat selection abilities of large compared to small species (e.g. Rundle et al. 2007).

We observed weak congruence in community composition between the studied organism groups. The strongest congruence was observed between phytoplankton and zooplankton, with a stronger similarity of regulatory environmental factors when compared to macroinvertebrates. Vilmi et al. (2016) previously reported rather similar levels of congruence among littoral epilithic diatom, bacterial and macroinvertebrate communities, albeit no significant congruence between macroinvertebrates and bacteria. Among wetland ponds, Soininen et al. (2007) did not find significant community congruence between phytoplankton and zooplankton. The level of congruence they observed was lower than that observed by us, whereas phytoplankton communities were more strongly structured by local environmental and zooplankton metacommunities by spatial factors across these wetland ponds. The analysis of phytoplankton, zooplankton and littoral macroinvertebrate assemblage congruence across lakes and 10 years revealed that levels of congruence between organism groups varied strongly between years (Bowman et al. 2008). For example, Mantel correlation ( $r$ values) between phytoplankton and macroinvertebrates varied from -0.14 to 0.65 depending on the year. Similar to our results, Bowman et al. (2008) observed generally stronger congruence between phytoplankton and 
zooplankton than between these groups and macroinvertebrates. However, Jyväsjärvi et al. (2014) observed significant among-lake congruence in assemblage composition of pelagic phytoplankton and macroinvertebrates, which remained after controlling for primary explanatory factors, thereby suggesting functional dependency between these groups.

Patterns in species richness

Phytoplankton species richness correlated positively with total phosphorus in our study lake basins. However, according to our analyses, only basin-level spatial effects explained some unique proportion of variation in phytoplankton richness. There was a positive relationship between phytoplankton richness and total phosphorus concentration, but all variation explained by total phosphorus was shared with the dummy lake basin factor. Earlier studies have detected unimodal response of phytoplankton species richness to wide nutrient gradients, where species richness peaks in eutrophic lakes but declines in hypertrophic lakes (Dodson et al. 2000; Jeppesen et al. 2000). However, this diversity-productivity relationship among lakes may be non-significant or negative after controlling of other factors including abundance of submerged macrophytes (Declerck et al. 2005).

Water depth was the strongest determinant of zooplankton species richness. The greater species richness of zooplankton in shallow water might be due to the daytime aggregation of pelagic species among macrophytes (Lauridsen et al. 1996; Folt and Burns 1999; Burks et al. 2002; van Donk and van de Bund 2002), in combination with additional species inhabiting macrophyte beds and stony substratum habitats (Walseng et al. 2006). We also observed a weak positive relationship between crustacean zooplankton richness and total phosphorus. In an earlier study along much wider trophic gradient, Jeppesen et al. (2000) observed negative among-lake response of zooplankton richness to nutrients. However, this relationship may rather be unimodal after taking into account the effects of macrophyte abundance and lake area on zooplankton richness (Declerck et al. 2005).

In our study, the species richness of littoral macroinvertebrates was associated only with habitat conditions. This observation is different from the results of Tolonen et al. (2017), who found in their within-lake within-habitat (for stony bottoms) study that the species richness of shallow littoral macroinvertebrates was only associated with the spatial factors. We suggest that differences in these observations may relate to the differences in the spatial scales and lengths in the environmental gradients between studies, whereas much narrower depth gradients $(<0.5 \mathrm{~m})$ and habitat variability were examined in Tolonen et al. (2017). In this study, we observed that macroinvertebrate richness was unimodally associated with water depth peaking at the intermediate depths along the studied depth gradient $(0-3 \mathrm{~m})$. We also observed positive relations of bottom slope and abundance of emergent macrophytes to macroinvertebrate diversity (see also Tolonen et al. 2005).

We did not find significant congruence in species richness among the littoral organism groups examined. The strongest, but very weak, species richness association was between phytoplankton and zooplankton. Comparable levels of low species richness correlation among organism groups have earlier been reported by several studies in lakes (e.g. Allen et al. 1999a, b) and in running waters (e.g. Heino et al. 2005). However, stronger congruence may exist among the species richness of different taxonomic hierarchies (e.g. families or orders) within these organism groups (e.g. among taxa of macroinvertebrates, see Bilton et al. 2006; Heino et al. 2009).

\section{Conclusions and implications}

Regarding organisms' responses to the environment at different spatial scales, our results implied that the communities of macroinvertebrates and crustacean zooplankton are more effectively tracking within-lake spatial variations in local environmental conditions, which may be related to the responses of these motile organisms to abiotic and biotic environment by the active selection of their habitats. On the other hand, we observed a high similarity of phytoplankton assemblages at within-basin scale, but clearly distinct phytoplankton assemblages at larger among-basin scale. We observed low levels of congruence in community composition and species richness among organism groups comparable to earlier studies at among-lake (Allen et al. 1999a, b) and within-lake (Vilmi et al. 2016) scales. Our analyses focused on relatively small spatial scale variation in assemblage structure and species richness, yet our findings were 
rather similar to previous studies at greater geographic scales showing very weak congruence (Heino 2010). Congruence among functionally and taxonomically divergent organism groups, such as among phytoplankton, zooplankton and macroinvertebrates in our study, is weaker than among-taxon congruence within a single group of organisms (e.g. macroinvertebrates) (Bilton et al. 2006; Heino et al. 2009). Therefore, including all major groups of organisms and search for robust indicator taxa within each group (e.g. EPT taxa among macroinvertebrates, Lenat 1993) may be more feasible for cost-effective environmental monitoring and biodiversity conservation than to use one group of organisms to indicate overall biodiversity. Our results also suggest that the factors influencing species composition and diversity of zooplankton may be rather distinct from the factors influencing phytoplankton and macroinvertebrate metacommunities. Omitting zooplankton from the ecological status assessment system of lakes under the EU WFD (EC 2000) has decreased research activity on this functionally important group. Both zooplankton and benthic macroinvertebrates have fundamental roles in secondary production, supporting fish production and further aquatic ecosystem service supply for human societies (Vadeboncoeur et al. 2002). Relatively low research and monitoring activities focused on zooplankton communities during the last two decades, which may hinder our understanding of human impacts and environmental change on lake ecosystem functioning and trophic relationships in aquatic food webs (Jeppesen et al. 2011).

Our results provide information on the effects of environmental and spatial factors on less studied lake littoral communities. Although our results suggested generally more important effects of environmental filtering on the community composition and species richness of littoral organisms, we also observed significant spatial effects both at within-basin and among-basin scales. Therefore, these results also highlight the importance of spatial factors for environmental monitoring and biodiversity assessments. Our analyses suggest that distinct lake littoral communities are structured by different ecological drivers. Therefore, observed low community congruence between aquatic organism groups probably relates to their distinct environmental responses and does not support use of surrogate groups or taxa for assessment and conservation purposes (see also Heino 2010; Westgate et al. 2014).

Acknowledgements Open access funding provided by Finnish Environment Institute (SYKE). Authors acknowledge the technical staff of the University of Joensuu for their help in the field sampling. We also thank Maa-ja Vesitekniikan tuki ry (Grant No. 13-7883-20), Academy of Finland, Maj and Tor Nessling Foundation, the EU Project FRESHABIT LIFE IP (LIFE14 IPE/FI/023) and the Youth Innovation Promotion Association CAS (2020316) for financial support of this study. We thank editors of Aquatic Ecology and two anonymous reviewers for insightful comments that improved this paper.

Open Access This article is licensed under a Creative Commons Attribution 4.0 International License, which permits use, sharing, adaptation, distribution and reproduction in any medium or format, as long as you give appropriate credit to the original author(s) and the source, provide a link to the Creative Commons licence, and indicate if changes were made. The images or other third party material in this article are included in the article's Creative Commons licence, unless indicated otherwise in a credit line to the material. If material is not included in the article's Creative Commons licence and your intended use is not permitted by statutory regulation or exceeds the permitted use, you will need to obtain permission directly from the copyright holder. To view a copy of this licence, visit http://creativecommons.org/licenses/by/4.0/.

\section{References}

Alahuhta J, Kanninen A, Hellsten S, Vuori KM, Kuoppala M, Hämäläinen H (2013) Environmental and spatial correlates of community composition, richness and status of boreal lake macrophytes. Ecol Indic 32:172-181

Allen AP, Whittier TR, Kaufmann PR, Larsen DP, O'Connor RJ, Hughes RM, Stemberger RS, Dixit SS, Brinkhurst RO, Herlihy AT, Paulsen SG (1999a) Corcordance of taxonomic richness patterns across multiple assemblages in lakes of the northeastern United States. Can J Fish Aquat Sci 56:739-747

Allen AP, Whittier TR, Larsen DP, Kaufmann PR, O'Connor RJ, Hughes RM, Stemberger RS, Dixit SS, Brinkhurst RO, Herlihy AT, Paulsen SG (1999b) Concordance of taxonomic composition patterns across multiple lake assemblages: effects of scale, body size, and land use. Can J Fish Aquat Sci 56:2029-2040

Bilton DT, McAbendroth L, Bedford A, Ramsay PM (2006) How wide to cast the net? Cross-taxon congruence of species richness, community similarity and indicator taxa in ponds. Freshw Biol 51:578-590

Blanchet FG, Legendre P, Borcard D (2008) Forward selection of explanatory variables. Ecology 89:2623-2632

Blukacz EA, Shuter BJ, Sprules WG (2009) Towards understanding the relationship between the wind conditions and plankton patchiness. Limnol Oceanogr 54:1530-1540 
Bowman MF, Ingram R, Reid RA, Somers KM, Yan ND, Paterson AM, Morgan GE, Gunn JM (2008) Temporal and spatial concordance in community composition of phytoplankton, zooplankton, macroinvertebrate, crayfish and fish on the precambrian shield. Can J Fish Aquat Sci 65:919-932

Brauns M, Garcia XF, Pusch MT, Walz N (2007) Eulittoral macroinvertebrate communities of lowland lakes: discrimination among trophic states. Freshwater Biol 52:1022-1032

Burks RL, Lodge DM, Jeppesen E, Lauridsen TL (2002) Diel horizontal migration of zooplankton: costs and benefits of inhabiting the littoral. Freshw Biol 47:343-365

Cardoso LDS, Motta Marques DD (2009) Hydrodynamics-driven plankton community in a shallow lake. Aquat Ecol 43:73-84

De Bie T, De Meester L, Brendonck L, Martens K, Goddeeris B, Ercken D, Hampel H, Denys L, Vanhecke L, Van der Kucht K, Van Vichelen J, Vyverman W, Declerck SAJ (2012) Body size and dispersal mode as key traits determining metacommunity structure of aquatic organisms. Ecol Lett 15:740-747

de Morais GF, dos Santos LG, Ortega JCG, Heino J, Bini LM (2018) Biological surrogates: a word of caution. Ecol Indic 88:214-218

Declerck S, Vandekerkhove J, Johansson L, Muylaert K, CondePorcuna JM, Van der Gucht K, Pérez-Martínez C, Lauridsen T, Schwenk K, Zwart G, Rommens W, LópezRamos J, Jeppesen E, Vyverman W, Brendonck L, De Meester L (2005) Multi-group biodiversity in shallow lakes along a gradients of phosphorus and water plant cover. Ecology 86:1905-1915

Declerck SAJ, Coronel J, Legendre P, Brendonck L (2011) Scale dependency of processes structuring metacommunities of cladocerans in temporary pools of High-Andes wetlands. Ecography 34:296-305

Dodson SI, Arnott SE, Cottingham KL (2000) The relationship in lake communities between primary productivity and species richness. Ecology 81:2662-2679

Dray S, Pelissier R, Couteron P, Fortin MJ, Legendre P, PeresNeto PR, Bellier E, Bivand R, Blanchet FG, De Cáceres M, Dufour AB, Heegard E, Jombart T, Munoz F, Oksanen J, Thioulouse J, Wagner HH (2012) Community ecology in the age of multivariate multiscale spatial analysis. Ecol Monogr 82:257-275

Duarte CM, Kalff J (1986) Littoral slope as a predictor of the maximum biomass of submerged macrophyte communities. Limnol Oceanogr 31:1072-1080

Duarte CM, Agustí S, Canfield DE (1992) Patterns in phytoplankton community structure in Florida lakes. Limnol Oceanogr 37:155-161

EC (2000) Directive 2000/60/EC of the European Parliament and of the Council of 23 October 2000 establishing a framework for community action in the field of water policy. Off J Eur Communities 43:1-72

EC (2011) Our life insurance, our natural capital: an EU biodiversity strategy to 2020. COM 2011:244

Folt CL, Burns CW (1999) Biological drivers of zooplankton patchiness. Trends Ecol Evol 14:300-305

Gaston KJ (2000) Global patterns in biodiversity. Nature 405:220-227
Gulati RD, van Donk E (2002) Lakes in the Netherlands, their origin, eutrophication and restoration: state-of-the-art review. Hydrobiologia 478:73-106

Hairston NG, Van Brunt RA, Kearns CM, Engstrom DR (1995) Age and survivorship of diapausing eggs in a sediment egg bank. Ecology 76:1706-1711

Havel JE, Shurin JB (2004) Mechanisms, effects, and scales of dispersal in freshwater zooplankton. Limnol Oceanogr 49:1229-1238

Heino J (2010) Are indicator groups and cross-taxon congruence useful for predicting biodiversity in aquatic ecosystems? Ecol Indic 10:112-117

Heino J (2013) Does dispersal ability affect the relative importance of environmental control and spatial structuring of littoral macroinvertebrate communities? Oecologia 171:971-980

Heino J (2015) Approaches, potentials and pitfalls of applying bioindicators in freshwater ecosystems. In: Lindenmayer DB, Pierson J, Barton P (eds) Surrogates and indicators of biodiversity and environmental change. CSIRO Publishing and CRC Press, Melbourne and London, pp 91-100

Heino J, Tolonen KT (2017) Ecological drivers of multiple facets of beta diversity in a lentic macroinvertebrate metacommunity. Limnol Oceanogr 62:2431-2444

Heino J, Paavola R, Virtanen R, Muotka T (2005) Searching for biodiversity indicators in running waters: Do bryophytes, macroinvertebrates, and fish show congruent diversity patterns? Biodivers Conserv 14:415-428

Heino J, Tolonen KT, Kotanen J, Paasivirta L (2009) Indicator groups and congruence of assemblage similarity, species richness and environmental relationships in littoral macroinvertebrates. Biodivers Conserv 18:3085-3098

Heino J, Melo AS, Siqueira T, Soininen J, Valanko S, Bini LM (2015) Metacommunity organisation, spatial extent and dispersal in aquatic systems: patterns, processes and prospects. Freshw Biol 60:845-869

Hilt S, Gross EM (2008) Can allelopathically active submerged macrophytes stabilise clear-water states in shallow lakes? Basic Appl Ecol 9:422-432

Jarnagin ST, Swan BK, Kerfoot WC (2000) Fish as vectors in the dispersal of Bythotrephes cederstroemi: diapausing eggs survive passage through the gut. Freshw Biol 43:579-589

Jeppesen E, Jensen JP, Søndergaard M, Lauridsen T (1999) Trophic dynamics in turbid and clearwater lakes with special emphasis on the role of zooplankton for water clarity. Hydrobiologia 408(409):217-231

Jeppesen E, Jensen JP, Søndergaard M, Lauridsen T, Landkildehus F (2000) Trophic structure, species richness and biodiversity in Danish lakes: changes along a phosphorus gradient. Freshw Biol 45:201-218

Jeppesen E, Jensen JP, Jensen C, Faafeng B, Hessen DO, Søndergaard M, Lauridsen T, Brettum P, Christoffersen K (2003) The impact of nutrient state and lake depth on topdown control in the pelagic zone of lakes: a study of 466 lakes from the temperate zone to the arctic. Ecosystems 6:313-325

Jeppesen E, Nõges P, Davidson TA, Haberman J, Nõges T, Blank K, Lauridsen TL, Søndergaard M, Sayer C, Laugaste R, Johansson LS, Bjerring R, Amsinck SL (2011) Zooplankton as indicators in lakes: a scientific-based plea for 
including zooplankton in the ecological quality assessment of lakes according to the European water framework directive (WFD). Hydrobiologia 676:279-297

Johnson RK, Goedkoop W (2002) Littoral macroinvertebrate communities: spatial scale and ecological relationships. Freshw Biol 47:1840-1854

Jyväsjärvi J, Järvinen M, Hämäläinen H (2014) Spatial community concordance of summer phytoplankton and profundal macroinvertebrates in boreal lakes. Can J Fish Aquat Sci 71:1776-1783

Landeiro VL, Bini LM, Costa FRC, Franklin E, Nogueira A, de Souza JLP, Moraes J, Magnusson WE (2012) How far can we go in simplifying biomonitoring assessments? An integrated analysis of taxonomic surrogacy, taxonomic sufficiency and numerical resolution in a megadiverse region. Ecol Indic 23:366-373

Lauridsen T, Pedersen LJ, Jeppesen E, Søndergaard M (1996) The importance of macrophyte bed size for cladoceran composition and horizontal migration in a shallow lake. J Plankton Res 18:2283-2294

Leibold MA, Holyoak M, Mouquet N, Amarasekare P, Chase JM, Hoopes MF, Holt RD, Shurin JB, Law R, Tilman D, Loreau M, Gonzalez A (2004) The metacommunity concept: a framework for multi-scale community ecology. Ecol Lett 7:601-613

Lenat DR (1993) Biotic index for the southeastern United States: derivation and list of tolerance values, with criteria for assigning water-quality ratings. J N Am Benthol Soc 12:279-290

Maloufi S, Catherine A, Mouillot D, Louvard C, Couté A, Bernard C, Trousselier M (2016) Environmental heterogeneity among lakes promotes hyper $\alpha$-diversity across phytoplankton communities. Freshw Biol 61:633-645

McFarland B, Carse F, Sandin L (2010) Littoral macroinvertebrates as indicators of lake acidification within the UK. Aquatic Conserv Mar Freshw Ecosyst 20:S105-S116

Mouquet N, Loreau M (2003) Community patterns in sourcesink metacommunities. Am Nat 162:544-557

National Board of Waters and the Environment (1981) Vesihallinnon analyysimenetemät. Tiedotus 213. Helsinki, Vesihallitus

Nõges P, Tuvikene L, Feldmann T, Tõnno I, Künnap H, Luup H, Salujõe J, Nõges T (2003) The role of charophytes in increasing water transparency: a case study of two shallow lakes in Estonia. Hydrobiologia 506-509:567-573

Oksanen J, Blanchet FG, Kindt R, Legendre P, Minchin PR, O'Hara RB, Simpson GL, Solymos P, Stevens MHH, Wagner H (2013) vegan: community ecology package. R-package ver. 2.0-9. https://CRAN.R-project.org/ package =vegan

Pluntke T, Kozerski HP (2003) Particle trapping on leaves and on the bottom in simulated submerged plant stands. Hydrobiologia 506-509:575-581

Reid AJ, Carlson AK, Creed IF, Eliason EJ, Gell PA, Johnson PTJ, Kidd KA, MacCormack TJ, Olden JD, Ormerod SJ, Smol JP, Taylor WW, Tockner K, Vermaire JC, Dudgeon D, Cooke SJ (2019) Emerging threats and persistent conservation challenges for freshwater biodiversity. Biol Rev 94:849-873

Rundle SD, Bilton DT, Foggo A (2007) By wind, wings or water: body size, dispersal and range size in aquatic invertebrates. In: Hildrew AG, Raffaelli DG, EdmondsBrown R (eds) Body size: the structure and function of aquatic ecosystems. Cambridge University Press, Cambridge, pp 186-209

Scheffer M, Hosper SH, Meijer M-L, Moss B, Jeppesen E (1993) Alternative equilibria in shallow lakes. Trends Ecol Evol 8:275-279

Soininen J, Luoto M (2012) Is catchment productivity a useful predictor of taxa richness in lake plankton communities? Ecol Appl 22:624-633

Soininen J, Kokocinski M, Estlander S, Kotanen J, Heino J (2007) Neutrality, niches, and determinants of plankton metacommunity structure across boreal wetland ponds. Ecoscience 14:146-154

Soininen J, Korhonen JJ, Karhu J, Vetterli A (2011) Disentangling the spatial patterns in community composition of prokaryotic and eukaryotic lake plankton. Limnol Oceanogr 56:508-520

Tolonen KT (2004) Patterns in diversity and assemblages of lake littoral macroinvertebrates in relation to abiotic and biotic factors. University of Joensuu, PhD Dissertations in Biology 27:1-27

Tolonen KT, Hämäläinen H (2010) Comparison of sampling methods and habitat types for detecting impacts on lake littoral macroinvertebrate assemblages along a gradient of human disturbance. Fundam Appl Limnol 176:43-59

Tolonen KT, Hämäläinen H, Holopainen IJ, Karjalainen J (2001) Influences of habitat type and environmental variables on littoral macroinvertebrate communities in a large lake system. Arch Hydrobiol 152:39-67

Tolonen KT, Holopainen IJ, Hämäläinen H, Rahkola-Sorsa M, Ylöstalo P, Mikkonen K, Karjalainen J (2005) Littoral species diversity and biomass: concordance among organismal groups and the effects of environmental variables. Biodivers Conserv 14:961-980

Tolonen KT, Vilmi A, Karjalainen SM, Hellsten S, Sutela T, Heino J (2017) Ignoring spatial effects results in inadequate models for variation in littoral macroinvertebrate diversity. Oikos 126:852-862

Tolonen KT, Cai Y, Vilmi A, Karjalainen SM, Sutela T, Heino J (2018) Environmental filtering and spatial effects on metacommunity organisation differ among littoral macroinvertebrate groups deconstructed by biological traits. Aquat Ecol 52:119-131

Vadeboncoeur Y, Vander Zanden MJ, Lodge DM (2002) Putting the lake back together: reintegrating benthic pathways into lake food web models. Bioscience 52:44-54

van Donk E, van de Bund WJ (2002) Impact of submerged macrophytes including charophytes on phyto- and zooplankton communities: allelopathy versus other mechanisms. Aquat Bot 72:261-274

Vilmi A, Karjalainen SM, Nokela T, Tolonen K, Heino J (2016) Unravelling the drivers of aquatic communities using disparate organismal groups and different taxonomic levels. Ecol Indic 60:108-118

Walseng B, Hessen DO, Halvorsen G, Schartau AK (2006) Major contribution from littoral crustaceans to zooplankton species richness in lakes. Limnol Oceanogr 51:2600-2606 
Watson SB, McCauley E, Downing JA (1997) Patterns in phytoplankton taxonomic composition across temperate lakes of differing nutrient status. Limnol Oceanogr 42:487-495

Westgate MJ, Barton PS, Lane PW, Lindenmayer DB (2014) Global meta-analysis reveals low consistency of biodiversity congruence relationships. Nat Commun 5:3899

White J, Irvine K (2003) The use of littoral mesohabitats and their macroinvertebrate assemblages in the ecological assessment of lakes. Aquat Conserv Mar Freshw Ecosyst $13: 331-351$

Publisher's Note Springer Nature remains neutral with regard to jurisdictional claims in published maps and institutional affiliations. 